\title{
Pengaruh Strategi Heuristik Pada Pendekatan Pemecahan Masalah Dalam Pembelajaran Matematika Kelas VIII SMP
}

\author{
Dewi Pramita ${ }^{1}$, Muh. Rusmayadi ${ }^{2}$ \\ ${ }^{1}$ Pendidikan Matematika, Universitas Muhammadiyah Mataram, Indonesia, mitha dhewi@yahoo.com \\ ${ }^{2}$ Pendidikan Matematika, Universitas Nahdlatul Wathan Mataram, Indonesia, muh.rusmayadi@gmail.com
}

\section{INFO ARTIKEL}

Riwayat Artikel:

Diterima: 09-08-2018

Disetujui: 16-10-2018

\section{Kata Kunci:}

Strategi Heuristik, Pemecahan Masalah

\begin{abstract}
ABSTRAK
Abstrak: Tujuan penelitian ini adalah untuk mengetahui pengaruh strategi heuristik pada pendekatan pemecahan masalah matematika siswa di kelas VIII SMP pada materi Sistem Persamaan Linear Dua Variabel. Jenis penelitian ini adalah quasi eksperimen. Populasi dari penelitian ini adalah siswa kelas VIII SMP. Instrument yang digunakan adalah tes yang berjumlah 6 soal uraian. Hasil penelitian menunjukkan bahwa rata-rata hasil posttest kelas eksperimen sebesar 65,8 dan nilai rata-rata kelas kontrol sebesar 58,68. Hasil uji-t diperoleh t-hitung sebesar 2.53 dan t-tabel sebesar 2,02. Hal ini menunjukkan bahwa hasil belajar antara siswa kelas eksperimen dan kelas kontrol terdapat perbedaan yang signifikan setelah diberikan perlakuan berbeda. Sehingga strategi heuristik pada pendekatan pemecahan masalah yang digunakan lebih berpengaruh terhadap hasil belajar siswa dibandingkan dengan metode pembelajaran langsung pada materi persamaan linear dua variabel.
\end{abstract}

\begin{abstract}
The purpose of this study was to determine the effect of heuristic strategies on the mathematical problem solving approach of students in class VIII of Junior High School on the material of Two Variable Linear Equation Systems. This type of research is quasi-experimental. The population of this study was the eighth grade students of junior high school. The instrument used is a test which amounts to 6 questions. The results showed that the average results of the experimental class posttest were 65.8 and the control class average value was 58.68. The $t$-test results obtained t-count of 2.53 and $t$-Tabel of 2.02. This shows that the learning outcomes between the experimental class students and the control class have significant differences after being given different treatments. So that the heuristic strategy in the problem solving approach used is more influential on student learning outcomes compared to the direct learning method in the two-variable linear equation material
\end{abstract}

\section{A. LATAR BELAKANG}

Matematika sebagai salah satu disiplin ilmu merupakan pengetahuan yang sangat penting dan pengetahuan dasar yang diperlukan dalam kehidupan sehari-hari, dalam kesehariannya manusia tidak bisa terlepas dari peranan matematika. Matematika sebagai ilmu universal yang menjadi dasar perkembangan ilmu pengetahuan dan teknologi modern merupakan salah satu mata pelajaran yang harus di pelajari siswa SMP. Hal ini diperkuat dalam Peraturan Mentri Pendidikan Nasional Republik Indonesia Nomor 23 Tahun 2006 bahwa salah satu standar kompetensi lulusan SMP/MTs untuk mata pelajaran matematika adalah memiliki kemampuan berpikir logis, analitis, sistematis, kritis, dan kreatif, serta mempunyai kemampuan bekerja sama. Berdasarkan Undang -
Undang Republik Indonesia Nomor 20 Tahun 2003 tentang Sistem Pendidikan Nasional Bab X Pasal 37 ayat 1, bahwa kajian matematika antara lain: berhitung, ilmu ukur, dan aljabar dimaksudkan untuk mengembangkan logika dan kemampuan berfikir peserta didik. Penekanan pembelajaran matematika tidak hanya pada melatih keterampilan dan hafal fakta, tetapi pada pemahaman konsep (Suherman dkk, 2003: 63). Untuk menumbuhkan motivasi, kreatifitas dan kemampuan menganalisis siswa pada kegiatan pembelajaran khususnya dalam kegiatan belajar matematika, maka harus dikembangkan suatu strategi pembelajaran matematika yang tidak hanya mentransfer pengetahuan kepada siswa saja, tetapi juga membantu siswa untuk mencerna dan membentuk pengetahuan mereka agar mampu memecahkan masalah yang dihadapinya. 
Berdasarkan pengamatan dan wawancara dengan guru bidang studi yang telah dilakukan di SMP Negeri Satap Mataiyang Kabupaten Sumbawa Barat pada bidang studi metematika, rendahnya hasil belajar siswa kelas VIII ini disebabkan karena masih banyak siswa yang mengalami banyak kesulitan dalam menyelesaikan soal-soal yang berbentuk soal cerita. Kesulitan tersebut tampak pada pemahaman siswa terhadap soal matematika contohnya soal cerita dalam persamaan linear dua variabel, Sehingga untuk menyelesaikan soal tersebut perlu terlebih dahulu siswa membaca soal dengan cermat dan menganalisa soal serta mamahami apa yang diketahui dan apa yang harus dicari, serta bagaimana langkah-langkah yang harus ditempuh untuk menyelesaikan soal tersebut. Jika siswa tidak memahami soal dengan baik maka jawaban (penyelesaiannya) bisa salah. Untuk hal yang demikian guru harus dapat menciptakan model pembelajaran untuk menyelesaikan dengan langkahlangkah yang benar agar siswa tidak mendapat kesulitan atau hambatan didalam belajar matematika. Pemecahan masalah sangat penting dalam pembelajaran matematika. karena proses pemecahan masalah akan menjadikan pemahaman siswa lebih baik.

Peran guru dalam pembelajaran pemecahan masalah bukan hanya sebagai perancang proses belajar mengajar, tetapi juga sebagai pembimbing atau fasilitator, dan motivator kepada siswa. Bimbingan diberikan apabila siswa mengalami kesulitan dalam proses pemecahan suatu masalah yang telah ditetapkan dalam tujuan pembelajaran. Model belajar pemecahan masalah mengharuskan guru menyiapkan masalah yang tepat untuk murid pada jenjang tertentu. Model ini pun dapat disusun jika siswa menghadapi masalah yang besar atau komplek, yang kemudian diarahkan kepada menemukan konsep atau prinsip tertentu, dengan demikian dalam proses pemecahan masalah siswa masih dibimbing oleh guru. Salah satu strategi untuk pemecahan masalah matematika adalah dengan memberikan penuntun - penuntun yang dapat mengarahkan siswa kearah pemecahan masalah yang disebut dengan strategi "Heuristik". Strategi ini bertumpu pada usaha-usaha seperti pemahaman atas apa yang diminta soal dari siswa, apa-apa yang sudah diketahui siswa serta bagaimana pengetahuan itu dapat digunakan untuk mengatasi kesulitan dari apaapa yang tidak diketahui oleh siswa. yang dapat mengarahkan siswa kearah pemecahan masalah yang disebut dengan strategi "heuristik". heuristik adalah penemuan untuk menemukan. Heuristik adalah suatu penuntun yang diperlukan dalam pemecahan suatu masalah, dan yang dapat mengarahkan pemecahan masalah untuk menemukan penyelesaian permasalahan yang ada.
Dalam pelaksanaannya dan implikasi dari pemecahan masalah tersebut, akan mampu meningkatkan daya nalar dan kemampuan matematis siswa dalam menyelesaikan masalah. Sehingga hal tersebut akan mampu mengarahkan kepada siswa untuk berfikir kritis dan sistematis sebagai problrm solver yang handal. Salah satu pendekatan pembelajaran yang mampu mewujudkan itu adalah penerapan pembelajaran dengan menggunakan strategi heuristik. Melalui strategi heuristik pada pendekatan pemecahan masalah siswa dituntut untuk menemukan konsep matematika dan membantu menemukan solusi dari sebuah masalah. akan dikembangkan pembelajaran matematika dengan strategi heuristik pada pendekatan pemecahan masalah dalam pembelajaran matematika. Berdasarkan masalah tersebut, maka peneliti tertarik untuk melaksanakan penelitian dengan judul "Pengaruh Strategi Heuristik pada Pendekatan Pemecahan Masalah Dalam Pembelajaran Matematika SMP Pada Materi Pokok Sistem Persamaan Linear Dua Variabel".

\section{B. METODE PENELITIAN}

Penelitian ini merupakan penelitian quasi eksprimen dimana tidak memungkinkan peneliti untuk mengontrol semua variable yang relevan kecuali dari beberapa variabel-variabel tersebut. Peneliti akan membagi menjadi dua kelompok, yaitu kelompok eksprimen (pendekatan pemecahan masalah dengan menggunakan strategi heuristik) dan kelompok kontrol (pendekatan pemecahan masalah tanpa menggunakan strategi heuristik). Desain peneliti yang digunakan dalam penelitian ini adalah Post-Test Only Control Group Design, dengan pola desain Posttest grop. Pada penelitian ini terdapat dua kelompok penelitian yaitu kelompok eksperimen dan kelompok kontrol. Dimana kelompok eksperimen yaitu kelompok kelas yang diterapkan pembelajaran dengan menggunakan strategi heuristik, sedangkan kelompok kontrol merupakan kelompok yang menggunakan pembelajaran langsung. Setelah guru mengajarkan suatu materi dengan strategi heuristik, maka siswa kedua kelas diberikan tes akhir atau posttes. Sampel adalah bagian dari jumlah dan karakteristik yang dimiliki oleh populasi tersebut (Sugiyono, 2009: 118). Dalam penelitian ini akan diambil sampel sebanyak dua kelas. Sampel diambil dengan tehnik simple random sampling yaitu dengan memilih secara acak satu kelas sebagai kelas eksperimen yakni kelas VIII.A sebanyak 25 siswa, satu kelas sebagai kelas kontrol yakni kelas VIII.B sebanyak 19 siswa.

Data penelitian ini diambil dari hasil tes, menurut Djemari dalam Widoyoko, (2009 : 45) dimana tes adalah salah satu cara untuk menaksir besarnya kemampuan seseorang secara tidak langsung, yaitu melalui respons seseorang terhadap 
stimulus atau pertanyaan. Teknik ini digunakan untuk memperoleh data hasil belajar siswa kelas eksperimen dan kelas kontrol pada materi persamaan linear dua variabel yaitu dilakukan dengan tes uraian.

Instrument penelitian adalah semua alat yang digunakan untuk mengumpulkan, memeriksa, menyelidiki suatu masalah, atau mengumpulkan, mengolah, menganalisa dan menyajikan data-data secara sistematis serta objektif dengan tujuan memecahkan suatu persoalan atau menguji suatu hipotesis. Sedangkan menurut Arikunto (2010: 265), instrument penelitian adalah alat bantu yang dipilih dan digunakan oleh peneliti dalam kegiatanya mengumpulkan data agar kegiatan tersebut menjadi sistematis dan dipermudah olehnya. Jadi instrument yang digunakan dalam penelitian ini adalah Post test berupa soal uraian yang terdiri dari tujuh soal yang terlebih dahulu diuji validitas dan reliabilitasnya.

Uji hipotesis ini digunakan apakah ada perbedaan antara kedua kelas eksperimen dan kelas kontrol. Adapun langkah-langkah yang dilakukan untuk menguji hipotesis sebagai berikut:

1. Menentukan hipotesis $\left(\mathrm{H}_{0}\right)$ dan hipotesis $\left(\mathrm{H}_{\mathrm{a}}\right)$

2. Rumus hipotesis matematis

3. Menentukan taraf signifikan yaitu $\alpha=5 \%$

4. Menghitung harga uji statistic dengan menggunakan uji t, yakni:

$$
\mathrm{t}=\frac{\bar{x}_{1}-\bar{x}_{2}}{\sqrt{\frac{s_{1}^{2}}{n_{1}}+\frac{s_{2}^{2}}{n_{2}}-2 r\left(\frac{s_{1}}{\sqrt{n_{1}}}\right)\left(\frac{s_{2}}{\sqrt{n_{2}}}\right)}}
$$

Dimana $\overline{x_{1}}=$ rata-rata kelas eksperimen, $\overline{x_{2}}=$ rata-rata kelas control, $s_{1}=$ variansi data kelas eksperimen, $s_{2}=$ variansi data kelas control, $n_{1}=$ jumlah sampel kelas eksperimen, dan $n_{2}=$ jumlah sampel kelas control. Dari hasil rumus tersebut maka ditentukan kesimpulan dengan kriteria sebagai berikut.

1. Jika $t_{\text {hitung }}>t_{\text {tabel }}$ maka $\mathrm{H}_{0}$ ditolak dan $\mathrm{H}_{\mathrm{a}}$ diterima (artinya terdapat pengaruh terhadap pembelajaran dengan strategi heuristik pada pendekatan pemecahan masalah terhadap hasil belajar matematika pada materi persamaan linear dua variabel).

2. Jika $t_{\text {hitung }} \leq t_{\text {tabel }}$ maka $\mathrm{H}_{0}$ diterima dan $\mathrm{H}_{\mathrm{a}}$ ditolak (artinya tidak terdapat pengaruh pembelajaran strategi heuristik terhadap hasil belajar matematika pada materi sistem persamaan linear dua variabel).

\section{HASIL DAN PEMBAHASAN}

\section{Hasil Uji Coba Instrument Penelitian}

Sebelum instumen digunakan dalam pengumpulan data. Uji coba instrumen dilakukan untuk mengetahui tingkat validitas dan reabilitas instrument yang bertujuan mengetahui tingkat kepercayaan instrumen agar memperoleh kesimpulan penelitian yang benar. Uji coba instrument ini dilakukan terhadap siswa kelas IX sebanyak 27 responden. Sedangkan jenis instrument yang digunakan adalah tes essay dengan jumlah item pertanyaan sebanyak 7 soal. Tahapan selanjutnya adalah melakukan uji validitas dan uji reabilitas. Apabila instrument ini telah memenuhi syarat, maka pengumpulan data dan pengolahan data dapat dilakukan. Perhitungan validitas instrument penelitian dilakukan dengan menggunakan rumus korelasi product moment dari pearson. Diperoleh dari 7 item soal diperoleh item soal yang valid 6 (nomor item soal: 1,2,4,5,6,7) dan 1 tidak valid (nomor item soal: 3), dengan taraf signifikan $5 \%$, dimana nomor yang tidak valid tidak digunakan seperti pada Tabel 1 berikut.

TABEL 1

HASIL UJI VALIDITAS INSTRUMEN

\begin{tabular}{ccccl}
\hline Butir Soal & $\mathbf{N}$ & $\mathbf{r}_{\mathbf{x y}-h i t u n g}$ & $\mathbf{r}_{\mathbf{x y} \text {-tabel }}$ & Keputusan \\
\hline $\mathrm{X}_{1}$ & 27 & 0,7902 & 0,381 & Valid \\
\hline $\mathrm{X}_{2}$ & 27 & 0,5961 & 0,381 & Valid \\
\hline $\mathrm{X}_{3}$ & 27 & 0,1569 & 0,381 & Tidak valid \\
\hline $\mathrm{X}_{4}$ & 27 & 0,4502 & 0,381 & Valid \\
\hline $\mathrm{X}_{5}$ & 27 & 0,7902 & 0,381 & Valid \\
\hline $\mathrm{X}_{6}$ & 27 & 0,5063 & 0,381 & Valid \\
\hline $\mathrm{X}_{7}$ & 27 & 0,7581 & 0,381 & Valid \\
\hline
\end{tabular}

Uji reabilitas digunakan untuk mengetahui tingkat ketelitian instrument penelitian. Nilai - nilai untuk pengujian reliabilitas berasal dari skor- skor soal yang digunakan. Item yang tidak valid dan tidak dipakai tidak dilibatkan dalam pengujian reliabilitas. Dari contoh pengujian validitas sebelumnya, item yang dipakai terdiri dari enam soal. Hasil uji reliabilitas instrument pada sampel sebanyak 27 siswa dengan taraf signifikan 5\% maka diperoleh $r_{\text {tabel }}$ sebesar 0,381. Sedangkan hasil perhitungan diperoleh $r_{\text {hitung }}$ sebesar 1,888 Berdasarkan hasil perhitungan uji reliabilitas, maka dapat dikatakan bahwa instrument penelitian dinyatakan reliabel, dimana $r_{\text {hitung }}>r_{\text {tabel }}$.

\section{Hasil Tes Evaluasi}

Analisis data posttest dimaksudkan untuk mengetahui kemampuan akhir siswa setelah mendapat perlakuan. Oleh karna itu, pengujian yang dilakukan terhadap hasil posttest adalah pengujian untuk melihat perbedaan kedua rata- rata. Pengujian ini dilakukan dengan menguji $t$. Hal ini dapat dilakukan dengan asumsi data normal dan homogen. Artinya, sebelum melakukan uji t, maka harus melalui homogenitas dan uji normalitas terlebih dahulu.

\section{a. Uji Homogenitas Data Posttest}

Uji homogenitas untuk mengetahui varians dari kedua kelompok data, hasil uji homogenitas dapat dilihat pada tabel berikut. 
TABEL 2

HASIL UJI HOMOGENITAS DATA HASIL BELAJAR

\begin{tabular}{ccccc}
\multicolumn{1}{c}{ Kelas } & Varians & $\mathbf{F}_{\text {hit }}$ & $\mathbf{F}_{\text {tab }}$ & Keputusan \\
\cline { 1 - 2 } Eksperimen & 88.99 & 1.04 & 2.15 & Homogen \\
\cline { 1 - 2 } kontrol & 85.673 & & & \\
\hline
\end{tabular}

Berdasarkan Tabel 2 di atas disimpulkan bahwa varians posstest kelas eksperimen dan kelas kontrol adalah homogen karna $F_{\text {hitung }}<F_{\text {tabel. }}$.

\section{b. Uji Normalitas Data Posttest}

Hasil perhitungan uji normalitas data posttest dapat dilihat pada Tabel 3 berikut.

TABEL 3

HASIL UJI NORMALITAS DATA POSTTEST

\begin{tabular}{|l|c|c|l|}
\hline \multicolumn{1}{|c|}{ Kelas } & $\chi^{2}{ }_{\text {hitung }}$ & $\chi_{\text {tabel }}^{2}$ & Keputusan \\
\hline Control & 9,4806 & 11,07 & Normal \\
\hline Eksperimen & 5,028 & 11,07 & Normal \\
\hline
\end{tabular}

Berdasarkan Tabel 3 di atas dapat diambil kesimpulan bahwa $\chi_{\text {hitung }}^{2}<\chi_{\text {tabel }}^{2}$ dengan sampel kelas kontrol (n) $=19$ dan sampel kelas eksperimen $(\mathrm{n})=25$ pada taraf signifikan $5 \%$ maka data posttest kelas kontrol dan kelas eksperimen dinyatakan normal.

\section{c. Uji Hipotesis Data Posttest}

Pada uji normalitas dan homogenitas sebelumnya diketahui bahwa data posstest dari kedua kelompok dinyatakan normal dan homogen. Sehingga, pengujian data diteruskan pada analisis data selanjutnya yaitu uji hipotesis dengan menggunakan uji $-t$. Uji hipotesis dilakukan untuk mengetahui sejauh mana perbedaan hasil dilihat pada belajar matematika antara siswa kelas eksperimen dan kelas kontrol setelah adanya perlakuan. Oleh karna jumlah siswa pada kelas kontrol dan kelas eksperimen tidak sama banyak $\left(n_{1} \neq n_{2}\right)$ dan varians kedua kelompok adalah homogen $\left(\sigma_{1}=\sigma_{2}\right)$, maka sesuai dengan ketentuan uji $t$ dilakukan dengan menggunakan rumus polled varians. Adapun hasil uji $t$ nilai posttest kelas kontrol dan eksperimen dapat dapat dilihat pada Tabel 4 berikut.

TABEL 4

HASIL UJI DATA HASIL BELAJAR

\begin{tabular}{|c|c|c|c|}
\hline Dk & t-hitung & t-tabel & Keputusan \\
\hline 42 & 2.53 & 2,02 & $\mathrm{H}_{0}$ ditolak \\
\hline
\end{tabular}

Dari Tabel 4 terlihat bahwa nilai $t$-hitung $>\mathrm{t}$-tabel dengan demikian, Ho $\left(\mu_{1}=\mu_{2}\right)$ ditolak dan $\mathrm{H}_{a}\left(\mu_{1} \neq\right.$ $\mu_{2}$ )diterima. Artinya, terdapat perbedaan hasil belajar antara siswa kelas eksperimen yang diajarkan dengan strategi heuristik dengan kelas kontrol yang tidak menggunakan strategi heuristik pada materi sistem persamaan linear dua variabel pada kelas VIII SMP Negeri satap mataiyang kabupaten Sumbawa Barat.
Berdasarkan hasil analisis posttest terhadap kelas eksperimen dan kelas kontrol, maka dapat disimpulkan bahwa nilai rata-rata posttest kelas eksperimen adalah 65,8 lebih besar dibandingkan kelas kontrol 58,68. Disini dapat disimpulkan bahwa kemampuan akhir kelas eksperimen lebih tinggi dibandingkan kelas kontrol setelah proses pembelajaran dilaksanakan dan dengan memberikan strategi pembelajaran heuristik pada pendekatan pemecahan masalah dalam pembelajaran matematika untuk kelas eksperimen. Hal ini dapat dilihat dari hasil perhitungan diperoleh $t_{\text {hitung }}$ sebesar 2.50 dan $t_{\text {tabel }}$ sebesar 2,02. Hal ini menunjukkan bahwa kemampuan akhir yang dimiliki siswa kelas eksperimen dan kelas kontrol terdapat perbedaan signifikan setelah diberi perlakuan melalui metode pembelajaran yang berbeda.

Berdasarkan uraian tersebut, maka dapat dikatakan bahwa strategi pembelajaran heuristik pada pendekatan pemecahan masalah berpengaruh terhadap hasil belajar siswa. Hal ini dikarenakan dengan menggunakan strategi pembelajaran heuristik pada pendekatan pemecahan masalah, siswa diberikan kesempatan untuk aktif didalam proses menemukan sehingga memperoleh pemahaman yang mendalam.

\section{SIMPULAN DAN SARAN}

Berdasarkan hal-hal yang telah dikemukan pada pembahasan hasil penelitian, maka dapat diambil kesimpulan bahwa strategi heuristik pada pendekatan pemecahan masalah dalam pembelajaran matematika lebih berpengaruh terhadap hasil belajar siswa pada materi pokok Sistem Persamaan Linear Dua Variabel Kelas VIII SMP Negeri Satap Mataiyang Kabupaten Sumbawa Barat. Karna dengan strategi heuristik pada pendekatan pemecahan masalah siswa lebih mudah menemukan solusi dari suatu masalah matematika dan mendapatkan pemahaman yang lebih baik didalam proses pembelajaran. Berdasarkan hasil penelitian tersebut, penulis mengajukan beberapa saran, antara lain: (1) Kepada pihak sekolah dan pihak pengajar khususnya, hendaknya mempertimbangkan penggunaan strategi heuristik pada pendekatan pemecahan masalah sebagai alternative dalam proses pembelajaran; dan (2) Guru diharapkan membuat perangkat pembelajaran yang memudahkan siswa untuk melakukan proses menemukan sehingga pembelajaran dapat dilakukan dengan menggunakan strategi heuristik.

\section{REFERENSI}

[1] Andri. (2008). Strategi Heuristik Pada Pendekatan Pemecahan Masalah Dalam Pembelajaran Matematika. Skripsi, UIN Syarif Hidayatullah Jakarta.

[2] Arikunto, Suharsimi. (2010). Prosedur Penelitian Suatu Pendekatan Praktek. Jakarta: Rineka Cipta 
[3] Nuharini Dewi. (2008). Matematika konsep dan Aplikasinya untuk SMP/MTs kelas VIII. Siduarjo: Campion Smart.

[4] Purwanto. (2013). Evaluasi Hasil Belajar. Yogyakarta: Pustaka Pelajar

[5] Sudjana, Nana. (2012). Penilaian Hasil Belajar Mengajar. Jatim: SIC

[6] Sugiyono. (2013). Metodologi Penelitian Pendidikan (Pendekatan Kuantitatif, Kualitatif dan R\&D), Cet .X. Bandung: Alfabeta

[7] Suprijono, Agus. (2009). Cooperative Learning Teori Dan Aplikasi Paikem. Yogyakarta: Pustaka Pelajar

[8] Yudi Darma, Imam Sujadi. (2011). Efektivitas Strategi Heuristik dengan Pendekatan Metakognitif dan Pendekatan Investigasi Terhadap Kemampuan Pemecahan Masalah Matematika Pada Materi Pokok Barisan dan Deret Ditinjau dari Kreativitas Siswa Kelas XII Madrasah Aliyah di Pontianak. JMEE, 1(2), 72-82 